\section{Xenotransplantation trials 'should proceed but need guidelines'}

\begin{abstract}
Washington. A panel set up by the US Institute of Medicine (IOM) has concluded that the potential benefits of xenotransplantation - the transplantation of organs, cells or tissues from animals to humans - outweigh its risks. It therefore recommends that scientifically justified clinical trials of such transplants should go ahead, provided federal guidelines and other safeguards are put in place.

The recommendation comes in a report released this week by the IOM's Committee on Xenograft Transplantation, established in 1994 in response to increasing ethical and public health questions about xenotransplantation.

"When the science base for specific types of xenotransplants is judged sufficient and the appropriate safeguards are in place, well-chosen human xenotransplantation trials using animal cells, tissues and organs would be justified and should proceed," the report says.
\end{abstract}

Experiments with xenotransplantation of organs have not been carried out in the United States since the early 1990 s. But several proposals are now under review, including some involving tissue transplantation to patients with AIDS and Parkinson's disease.

A key recommendation of the committee is that all institutions and individuals carrying out xenotransplants should adhere to national standards. The Food and Drug Administration and the Centers for Disease Control and Prevention are developing such guidelines, which are expected to be released soon.

The committee rejected proposals for a national body, such as the Recombinant DNA Advisory Committee of the National Institutes of Health, to oversee experimenters and ensure that they comply with new federal standards. Instead, it said, "appropriate" supervision could be provided by increasing the resources of local Institutional Review Boards and animal care committees, and requiring them to adhere to the guidelines in evaluating specific protocols.

But it does recommend that the Department of Health and Human Services should establish an advisory committee to "coordinate but not to regulate" research, policy and surveillance issues.

The committee also points out that "ample evidence" for the transmission of infectious agents from animals to humans indicates a danger "unequivocally greater than zero" that xenotransplantation could introduce new and deadly viruses into humans.

M. W.

\title{
US plan to scrap DNA panel splits genetic researchers
}

Washington. US gene-therapy researchers and others appear to be split over a proposal to eliminate the Recombinant DNA Advisory Committee (RAC) of the National Institutes of Health (NIH), set up in the mid-1970s in response to public fears of genetic engineering.

In a notice published in the Federal Register last week, the NIH describes as "timely and appropriate" a plan made public in May by Harold Varmus, the director of NIH, to disband the 25-member panel of scientists, ethicists and others, now responsible for approving novel gene-therapy protocols, and to transfer this task to the Food and Drug Administration (FDA).

But the proposal, on which the public has until 7 August

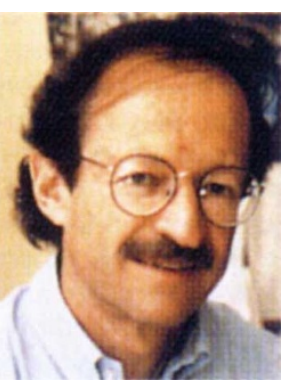
to comment, has Varmus: plans smaller been criticized by advisory committee.

politicians and scientists on the grounds that it will remove the possibility of public scrutiny of applications for experiments. (The FDA conducts reviews and approval meetings privately.)

In arguing for the RAC's dissolution, NIH cites the lack of novel protocols received under a new system of 'consolidated' review, initiated last year, under which unoriginal protocols, which make up 90 per cent of those received, are sent immediately to the FDA (see Nature 379, 668; 1996 \& 375, 713; 1995).

NIH also argues that public airing of issues would not be lost. "It is not the RAC per se that is critical for public accountability, but the system by which NIH continues to provide public discussion," the Federal Register notice states.

Under the new plan, the NIH would retain a smaller committee of six to ten members, to be known as the Office of Recombinant DNA Activities Advisory Committee (OAC). This would meet 'regularly', and would organize public conferences on new and controversial gene-therapy topics up to four times a year, but would not review or approve specific protocols.

Many scientists are delighted at Varmus's bid to eliminate what they see as an unwarranted bureaucratic burden. Paul Berg of Stanford University, one of the scientists whose concerns in the early 1970 s led to the setting up of the RAC, says: "The RAC has outlived its usefulness, and I don't see that it ever had any special competence for reviewing proposals for clinical trials." Although the proposed OAC would foster "very public discussions", it "would not be sitting in the approval pathway for proposals".

Ronald Crystal, a gene therapist at the New York Hospital-Cornell Medical Center and the first gene therapist to use adenovirus for in vivo gene therapy, says that as a clinical investigator he found RAC approval "comforting" in earlier days. But, he adds, "I don't think it's necessary any more. The newness of gene therapy is no longer there."

Others are concerned about the proposal. "The proposed quasi-RAC is just a whitewash, just window dressing," says W. French Anderson, a molecular geneticist at the University of Southern California, who pioneered ex vivo human gene therapy in 1990 by treating a girl lacking adenosine deaminase. Unlike the RAC, the new committee, he says, will not be able to "critically analyze protocols as they come in".

Anderson complains that the proposed conferences on novel topics, which would cover policy aspects of topics such as in utero gene therapy, would not allow the public scrutiny of specific proposals that is assured by the current system.

His concern is shared by Malcolm Brenner, director of the cell and genetherapy programme at St Jude's Children's Research Hospital in Memphis, Tennessee, and one of the earliest applicants to the RAC. Varmus's proposed conferences are "not going to get down to the nitty-gritty" of specific protocols, says Brenner.

He maintains that, whereas the RAC "compelled" researchers to discuss their plans publicly, "the FDA certainly won't do that". But Philip Noguchi, director of the FDA's cellular and gene therapies division, insists that "public oversight is still going to be there".

Another critic is Sheldon Krimsky, a former member of RAC and a science policy analyst at Tufts University in Medford, Massachusetts. Krimsky claims that the spectre of genetic manipulation for cosmetic ends opens an ethical Pandora's box. "We may be short-cutting the type of public dialogue that would be necessary for sound public policy," he says.

There is also disquiet in Congress, where some politicians have noted with alarm the proposal to disband the RAC. The subcommittee of the Senate appropriations committee that controls the NIH's \$12-billion or so budget last month asked Varmus for written justification of the proposal.

But it is not clear that Congress as a whole will rally to the RAC's defence. Senator Edward Kennedy (Democrat, Massachusetts), for example, often outspoken on such issues, has so far declined to take a stand.

Meredith Wadman 